\title{
Genetic Divergence Among Safflower Genotypes (Carthamus tinctorius L.) by Multivariate Analyzes
}

\author{
C. da S. Costa ${ }^{2}$, V. P. Silva ${ }^{1}$, J. P. E. Lira ${ }^{2}$, R. Felipin-Azevedo², T. A. S. Gilio ${ }^{2}$, \\ L. G. Neves ${ }^{2} \&$ M. A. A. Barelli ${ }^{1,2}$ \\ ${ }^{1}$ Postgraduate Program in Biodiversity and Biotechnology, Bionorte Network, State University of Mato Grosso, \\ Mato Grosso, Brazil \\ ${ }^{2}$ Departament of Agronomy, State University of Mato Grosso, Cáceres, Mato Grosso, Brazil \\ Correspondence: V. P. Silva, Postgraduate Program in Biodiversity and Biotechnology-Bionorte Network, State \\ University of Mato Grosso, Mato Grosso, Brazil. Tel: 55-065-996-090-140. E-mail: silvabiologo@hotmail.com
}

Received: February 17, 2019 Accepted: March 20, $2019 \quad$ Online Published: May 15, 2019

doi:10.5539/jas.v11n6p363 URL: https://doi.org/10.5539/jas.v11n6p363

The research is financed by Conselho Nacional de Desenvolvimento Cientifico e Tecnológico-CNPq and Fundação de Amparo a Pesquisa do Estado de Mato Grosso-FAPEMAT.

\begin{abstract}
Carthamus tinctorius L. is an oil seed, used both for human consumption and for industrial purposes. It is a crop that presents wide adaptability to various ecophysiological conditions, although it presents great productive potential and wide adaptability, it is still necessary to obtain technical information regarding its cultivation and of cultivars adapted and improved. In this sense, the estimation of genetic divergence using multivariate techniques has become a common tool among breeders. In view of the above, this research aimed to evaluate the genetic divergence of safflower genotypes originate from the Germplasm Active Bank (BAG) of the Instituto Mato-grossense do Algodão (IMA-MT) by means of multivariate analysis, aiming at the extension of information of this culture. The genetic divergence was estimated using multivariate analysis based on the Euclidean average distance, using the clustering optimization methods of Tocher and Hierarchical "UPGMA". The results obtained allowed to identify the existence of genetic divergence among the evaluated genotypes, highlighting genotypes 5 and 38, which presented greater genetic divergence, constituting in potential sources of interest for the use in program of genetic improvement that aim at the development of superior cultivars of safflower.
\end{abstract}

Keywords: dissimilarity, oleaginous, genetic divergence

\section{Introduction}

Carthamus tinctorius L. is a member of the family Asteraceae, is an oilseed, used in both human and industrial purposes. It is a crop that presents a wide adaptability to several ecophysiological conditions, developing satisfactorily under low water availability in low fertility soils and in locations with temperature variations, thus being an alternative crop for Brazilian arid and semi-arid regions (Moura et al., 2015).

Although it presents great productive potential mainly due to the value of its oil and its wide adaptability, it is still scarce technical information about its cultivation and of cultivars adapted and improved in the Brazilian regions (Gerhardt, 2014). In this perspective, genetic improvement may help in this process, since one of the objectives of breeding is to increase the economic value of the species, increasing productivity, resistance to diseases and nutritional quality (Borém \& Miranda, 2005).

For a breeding program to be successful there is a need for genetic divergence in populations that will be subjected to selection, that is, genetic variability in the population (Ivoglo et al., 2008). The genetic diversity is evaluated with the objective of identifying the hybrid combinations with greater heterotrophic effect, to identify the parents who, when crossed, allow the appearance of superior genotypes. In addition, the study of genetic divergence is important for the monitoring of germplasm banks, in addition to facilitating the knowledge of the genetic basis of the population (Ferrão et al., 2002; Cruz et al., 2004). 
Among the predictive methods used in estimates of genetic distance is the average Euclidean distance, where it can be estimated by taking as a base data without repetitions (Carvalho et al., 2003). The estimation of genetic divergence using multivariate techniques has become common among safflower breeders (Shivani et al., 2010; Safavi et al., 2012; Zoz, 2015; Pavithra et al., 2015; Atole et al., 2018).

In this sense, the present research aimed to evaluate the genetic divergence of safflower genotypes by means of multivariate analysis, aiming at the extension of information of this culture for safflower breeding programs.

\section{Materials and Methods}

\subsection{Site Localition and Characterization}

The experiment was carried out in the experimental area belonging to the Empresa Mato-Grossense de Pesquisa, Assistência e Extensão Rural (EMPAER), in the county of Cáceres, Mato Grosso state, located at latitude $16^{\circ} 43^{\prime} 42^{\prime \prime}$ South and longitude 57 $40^{\prime} 51^{\prime \prime}$ West with altitude of 118 meters, at BR 070, $12 \mathrm{~km}$ from Cáceres. The typical climate of the region, according to the classification of Köppen, is tropical, hot, humid and dry winter (Awa), with a period of rainfall ranging from October to April and from May to September (Dallacort et al., 2014). The soil is classified as Chernossolic Eutrophic Yellow Red Argissolo, with a medium clay texture (Arantes et al., 2012).

Were evalueted 50 safflower genotypes from the North American germplasm bank Western Regional Plant Introduction Station (WRPIS), obtained through the Germoplasm Resource Information Nertwork (GRIN), imported by Instituto Mato-Grossente de Algodão (IMAT-MT) and ceded to the Laboratory of Genetic Resources and Biotechnology (LRG\&B) of Universidade do Estado de Mato Grosso (UNEMAT), university campus of Cáceres (Table 1).

Table 1. Order, origin of the safflower genotypes belonging to the Laboratory of Genetic Resources and Biotechnology of Universidade do Estado de Mato Grosso

\begin{tabular}{lll|lll}
\hline Order & PI & Origin & Order & PI & Origin \\
\hline $\mathbf{1}$ & 193473 & Ethiopia & $\mathbf{2 6}$ & 283757 & India \\
$\mathbf{2}$ & 195895 & Morocco & $\mathbf{2 7}$ & 304438 & Iran \\
$\mathbf{3}$ & 237539 & Turkey & $\mathbf{2 8}$ & 305161 & India \\
$\mathbf{4}$ & 248385 & India & $\mathbf{2 9}$ & 305198 & India \\
$\mathbf{5}$ & 248620 & Pakistan & $\mathbf{3 0}$ & 305207 & India \\
$\mathbf{6}$ & 248808 & India & $\mathbf{3 1}$ & 305209 & India \\
$\mathbf{7}$ & 248828 & India & $\mathbf{3 2}$ & 305540 & Kazakhstan \\
$\mathbf{8}$ & 248839 & India & $\mathbf{3 3}$ & 306832 & India \\
$\mathbf{9}$ & 248852 & India & $\mathbf{3 4}$ & 306833 & India \\
$\mathbf{1 0}$ & 250083 & Egypt & $\mathbf{3 5}$ & 306838 & India \\
$\mathbf{1 1}$ & 250188 & Pakistan & $\mathbf{3 6}$ & 306844 & India \\
$\mathbf{1 2}$ & 250190 & Pakistan & $\mathbf{3 7}$ & 306866 & India \\
$\mathbf{1 3}$ & 250203 & Pakistan & $\mathbf{3 8}$ & 343783 & Iran \\
$\mathbf{1 4}$ & 250204 & Pakistan & $\mathbf{3 9}$ & 343930 & Ethiopia \\
$\mathbf{1 5}$ & 250840 & Iran & $\mathbf{4 0}$ & 367833 & Argentina \\
$\mathbf{1 6}$ & 250922 & Iran & $\mathbf{4 1}$ & 369842 & Armenia \\
$\mathbf{1 7}$ & 251978 & Turkey & $\mathbf{4 2}$ & 369845 & Tajikistan \\
$\mathbf{1 8}$ & 253540 & Hungary & $\mathbf{4 3}$ & 369849 & Russia \\
$\mathbf{1 9}$ & 253899 & Syria & $\mathbf{4 4}$ & 369854 & Uzbekistan \\
$\mathbf{2 0}$ & 259996 & Paskitan & $\mathbf{4 5}$ & 392029 & Turkey \\
$\mathbf{2 1}$ & 259997 & Paskitan & $\mathbf{4 6}$ & 392030 & Turkey \\
$\mathbf{2 2}$ & 262443 & Spain & $\mathbf{4 7}$ & 392031 & Turkey \\
$\mathbf{2 3}$ & 262447 & Kazakhstan & $\mathbf{4 8}$ & 393500 & India \\
$\mathbf{2 4}$ & 262450 & India & $\mathbf{4 9}$ & 401474 & Bangladesh \\
$\mathbf{2 5}$ & 279344 & Japan & $\mathbf{5 0}$ & 401475 & Bangladesh \\
\hline
\end{tabular}

Note. ${ }^{1}$ Plant Introduction. 


\subsection{Morphoagronomic Characterization}

The preparation of the experimental area was carried out in the conventional system, performing manual sowing on May 1st, 2018, with fertilization of $450 \mathrm{Kg} \mathrm{ha}^{-1}$ of formulated $\left(\mathrm{N} \mathrm{P}_{2} \mathrm{O}_{5} \mathrm{~K}_{2} \mathrm{O}\right)$ 4-14-8 according to culture recommendations. The plots of each genotype consisted of four lines with 1 meter of length, with spacing of 0.50 centimeters between rows and 0.10 centimeters between plants, having a total of 10 plants per line. Basic management measures, such as manual weeding and irrigation, have been adopted by sprinkling whenever necessary.

The following agronomic characteristics were evaluated: Days for flowering (DF), Plant cycle (CYCLE), Number of ramifications per plant (NRP), Plant height (PH), Number of seeds per chapter (NSC), Number of chapter per plant (NCP), Diameter of the chapter (DC), Diameter of the stalk (DS), Width of seeds (WS), Length of seeds (LS), Weight of 100 seeds (W100) and Plant yield (PY).

\subsection{Statistical Analyses}

Diversity among the 25 safflower genotypes genotypes for 12 traits was assessed by estimating Euclidean average distance. Based on this matrix, we used the Tocher optimization grouping methods and Hierarchical Method of Intermediate Cluster between Groups (UPGMA) to build the genetic distance between the genotypes in clusters. The criterion of Singh (1981) was also used to quantify the relative contribution of the characteristics to genetic divergence. All analyzes were performed using the computational resources of the Genes software (Cruz, 2013).

\section{Results and Discussion}

Table 2 shows the descriptive analysis of the twelve quantitative traits evaluated in the 50 safflower genotypes, where it is possible to observe that the genotypes showed an average flowering time of 84.5 days, with the genotypes PI248852 and PI250083 showing a shorter flowering time 75 days and the later flowering genotype PI248620 at 104 days. These results are superior to those obtained by Shinwari et al. (2014), in Islamabad-Pakistan, evaluating 122 genotypes collected from several geographic ecosystems in the world, where the average for this parameter was 175.2 days, with minimum and maximum values of 160 and 188 days, respectively.

In relation to the crop cycle, safflower genotypes presented values ranging from 118 to 156 days, and genotypes PI343783, PI193473, PI250083 and PI369849 showed to be early, while genotypes PI248620 and PI305209 were found to be late (Table 2). These values are similar to those of Pavithra et al. (2015), in which they obtained values from 128 to 148 days, evaluating 150 safflower accesses in the Karnataka region of India during the years 2011/12. According to Galant et al. (2015), the safflower cycle tends to vary from 130 to 150 days, and may be an option for growing in the dry season, or for the dry period in some Brazilian agricultural regions.

For the number of ramifications per plant, the average of the evaluated genotypes was 13.58 , and the genotypes PI248385, PI253899 and PI305198 presented values higher than 20 ramifications per plant (Table 2). Although this quantitative factor is important in the question of productivity, since the trend would be that the larger the number of branches the greater the number of inflorescences and consequently the greater the number of chapters, these characteristics should be carefully analyzed, since for the safflower crop, there is no interest in obtaining stalks with many ramifications due to differences in flowering rates within the chapter. Bellé et al. (2012), considers that many ramifications result in lack of uniformity in the anthesis, which reduces the quality of the stems. 
Table 2. Descriptive analysis of fifty safflower genotypes evaluated in the city of Cáceres, state of MatoGrosso

\begin{tabular}{|c|c|c|c|c|c|c|c|c|c|c|c|c|}
\hline \multirow{2}{*}{ Genotypes } & \multicolumn{12}{|c|}{ Characteristics evaluated } \\
\hline & DF & CYCLE & NRP & PH & NSC & NCP & DC & DS & WS & $\mathbf{L S}$ & W100 & PY \\
\hline PI193473 & 79.00 & 121.00 & 12.00 & 86.00 & 23.00 & 33.00 & 2.50 & 10.45 & 0.75 & 0.45 & 5.17 & 46.35 \\
\hline PI195895 & 88.00 & 150.00 & 20.00 & 111.00 & 33.00 & 55.00 & 2.48 & 12.05 & 0.71 & 0.41 & 4.94 & 26.13 \\
\hline PI237539 & 83.00 & 139.00 & 15.00 & 97.00 & 42.00 & 37.00 & 2.60 & 10.94 & 0.84 & 0.42 & 5.40 & 42.35 \\
\hline PI248385 & 83.00 & 123.00 & 21.00 & 82.00 & 19.00 & 43.00 & 2.07 & 8.11 & 0.72 & 0.40 & 3.88 & 19.98 \\
\hline PI248620 & 104.00 & 156.00 & 18.00 & 108.00 & 19.00 & 32.00 & 2.22 & 13.23 & 0.76 & 0.45 & 4.34 & 16.43 \\
\hline PI248808 & 81.00 & 130.00 & 19.00 & 72.00 & 10.00 & 48.00 & 2.39 & 9.71 & 0.71 & 0.40 & 6.04 & 39.33 \\
\hline PI248828 & 80.00 & 125.00 & 12.00 & 77.00 & 22.00 & 33.00 & 2.62 & 8.75 & 0.80 & 0.43 & 6.16 & 19.33 \\
\hline PI248839 & 83.00 & 143.00 & 9.00 & 95.00 & 28.00 & 41.00 & 2.68 & 10.78 & 0.85 & 0.47 & 6.04 & 19,41 \\
\hline PI248852 & 75.00 & 130.00 & 14.00 & 72.00 & 28.00 & 25.00 & 2.27 & 9.57 & 0.85 & 0.42 & 5.99 & 26.33 \\
\hline PI250083 & 75.00 & 121.00 & 14.00 & 90.00 & 17.00 & 48.00 & 2.18 & 10.15 & 0.75 & 0.47 & 4.45 & 21.00 \\
\hline PI250188 & 83.00 & 125.00 & 11.00 & 89.00 & 29.00 & 21.00 & 2.74 & 8.97 & 0.80 & 0.38 & 5.14 & 12.68 \\
\hline PI250190 & 75.00 & 125.00 & 11.00 & 82.00 & 24.00 & 36.00 & 2.55 & 9.30 & 0.93 & 0.47 & 5.50 & 33.66 \\
\hline PI250203 & 89.00 & 139.00 & 13.00 & 86.00 & 33.00 & 54.00 & 2.43 & 10.68 & 0.77 & 0.41 & 4.20 & 33.66 \\
\hline PI250204 & 79.00 & 123.00 & 9.00 & 66.00 & 22.00 & 32.00 & 2.44 & 8.82 & 0.73 & 0.45 & 5.11 & 17.21 \\
\hline PI250840 & 86.00 & 127.00 & 14.00 & 101.00 & 42.00 & 55.00 & 3.16 & 11.39 & 0.80 & 0.47 & 5.00 & 69.97 \\
\hline PI250922 & 77.00 & 123.00 & 15.00 & 73.00 & 31.00 & 31.00 & 2.67 & 10.50 & 0.89 & 0.51 & 7.10 & 39.67 \\
\hline PI251978 & 95.00 & 140.00 & 20.00 & 87.00 & 23.00 & 32.00 & 2.36 & 10.60 & 0.77 & 0.42 & 5.99 & 9.68 \\
\hline PI253540 & 88.00 & 139.00 & 12.00 & 93.00 & 14.00 & 22.00 & 2.67 & 10.93 & 0.80 & 0.48 & 5.95 & 12.53 \\
\hline PI253899 & 84.00 & 134.00 & 22.00 & 80.00 & 19.00 & 59.00 & 2.24 & 13.44 & 0.80 & 0.47 & 5.29 & 68.41 \\
\hline PI259996 & 81.00 & 150.00 & 12.00 & 77.50 & 24.00 & 32.00 & 2.89 & 10.38 & 0.81 & 0.50 & 4.57 & 38.26 \\
\hline PI259997 & 90.00 & 130.00 & 15.00 & 92.00 & 21.00 & 27.00 & 2.75 & 11.73 & 0.82 & 0.38 & 5.70 & 31.54 \\
\hline PI262443 & 78.00 & 150.00 & 20.00 & 62.00 & 22.00 & 48.00 & 1.98 & 12.00 & 0.78 & 0.35 & 3.86 & 24.35 \\
\hline PI262447 & 96.00 & 140.00 & 36.00 & 107.00 & 43.00 & 52.00 & 2.30 & 10.48 & 0.77 & 0.44 & 4.61 & 52.31 \\
\hline PI262450 & 85.00 & 132.00 & 23.00 & 82.00 & 30.00 & 33.00 & 2.26 & 9.49 & 0.75 & 0.43 & 4.33 & 27.23 \\
\hline PI279344 & 86.00 & 136.00 & 9.00 & 97.00 & 22.00 & 25.00 & 2.42 & 12.78 & 0.73 & 0.42 & 4.09 & 23.14 \\
\hline PI283757 & 84.00 & 156.00 & 16.00 & 70.00 & 24.00 & 20.00 & 2.10 & 11.86 & 0.80 & 0.44 & 3.76 & 14.00 \\
\hline PI304438 & 91.00 & 136.00 & 15.00 & 90.00 & 28.00 & 40.00 & 2.30 & 9.87 & 0.83 & 0.39 & 3.95 & 16.23 \\
\hline PI305161 & 88.00 & 136.00 & 18.00 & 89.00 & 26.00 & 27.00 & 2.31 & 9.92 & 0.79 & 0.44 & 4.34 & 19.98 \\
\hline PI305198 & 86.00 & 132.00 & 24.00 & 80.00 & 20.00 & 31.00 & 2.20 & 8.80 & 0.76 & 0.41 & 4.08 & 26.82 \\
\hline PI305207 & 83.00 & 132.00 & 16.00 & 94.00 & 29.00 & 39.00 & 2.98 & 12.05 & 0.80 & 0.42 & 5.60 & 70.28 \\
\hline PI305209 & 94.00 & 156.00 & 10.00 & 86.00 & 25.00 & 36.00 & 2.39 & 9.19 & 0.85 & 0.42 & 4.48 & 20.31 \\
\hline PI305540 & 94.00 & 139.00 & 22.00 & 104.00 & 37.00 & 49.00 & 2.29 & 11.29 & 0.87 & 0.45 & 5.12 & 15.69 \\
\hline PI306832 & 98.00 & 136.00 & 15.00 & 88.00 & 25.00 & 19.00 & 2.46 & 10.15 & 0.84 & 0.44 & 4.52 & 20.30 \\
\hline PI306833 & 77.00 & 123.00 & 11.00 & 85.00 & 38.00 & 23.00 & 2.94 & 9.44 & 0.73 & 0.40 & 5.39 & 31.30 \\
\hline PI306838 & 86.00 & 130.00 & 9.00 & 76.00 & 31.00 & 17.00 & 2.37 & 8.77 & 0.74 & 0.43 & 5.15 & 15.40 \\
\hline PI306844 & 84.00 & 134.00 & 11.00 & 80.00 & 23.00 & 25.00 & 2.29 & 9.52 & 0.73 & 0.46 & 5.87 & 21.90 \\
\hline PI306866 & 84.00 & 133.00 & 7.00 & 75.00 & 23.00 & 12.00 & 2.45 & 7.39 & 0.74 & 0.39 & 4.99 & 5.67 \\
\hline PI343783 & 79.00 & 118.00 & 7.00 & 56.00 & 42.00 & 6.00 & 2.59 & 7.00 & 0.60 & 0.44 & 4.04 & 15.89 \\
\hline PI343930 & 88.00 & 134.00 & 14.00 & 100.00 & 30.00 & 19.00 & 2.47 & 10.84 & 0.74 & 0.46 & 6.53 & 32.31 \\
\hline PI367833 & 81.00 & 132.00 & 10.00 & 80.00 & 37.00 & 25.00 & 2.72 & 9.67 & 0.91 & 0.45 & 4.31 & 14.20 \\
\hline PI369842 & 80.00 & 127.00 & 9.00 & 78.00 & 29.00 & 25.00 & 2.65 & 11.75 & 0.90 & 0.52 & 5.40 & 29.24 \\
\hline PI369845 & 79.00 & 125.00 & 6.00 & 62.00 & 47.00 & 23.00 & 2.80 & 9.46 & 0.82 & 0.44 & 4.68 & 45.91 \\
\hline PI369849 & 75.00 & 121.00 & 7.00 & 68.00 & 30.00 & 16.00 & 2.61 & 7.10 & 0.82 & 0.44 & 6.68 & 17.14 \\
\hline PI369854 & 82.00 & 143.00 & 7.00 & 70.00 & 22.00 & 19.00 & 2.39 & 9.15 & 0.89 & 0.42 & 4.85 & 15.43 \\
\hline PI392029 & 84.00 & 130.00 & 9.00 & 89.00 & 22.00 & 12.00 & 2.33 & 10.02 & 0.75 & 0.47 & 4.45 & 21.85 \\
\hline PI392030 & 95.00 & 139.00 & 9.00 & 100.00 & 18.00 & 16.00 & 2.60 & 10.89 & 0.80 & 0.46 & 4.30 & 14.03 \\
\hline PI392031 & 82.00 & 136.00 & 8.00 & 98.00 & 30.00 & 17.00 & 2.63 & 9.73 & 0.76 & 0.46 & 4.81 & 15.17 \\
\hline PI393500 & 82.00 & 143.00 & 9.00 & 88.00 & 10.00 & 21.00 & 2.19 & 9.12 & 0.89 & 0.52 & 6.20 & 8.79 \\
\hline PI401474 & 85.00 & 127.00 & 8.00 & 85.00 & 21.00 & 24.00 & 2.22 & 8.45 & 0.83 & 0.47 & 4.30 & 14.06 \\
\hline PI401475 & 81.00 & 125.00 & 6.00 & 71.00 & 33.00 & 16.00 & 2.54 & 9.50 & 0.89 & 0.47 & 5.09 & 18.68 \\
\hline Mean & 84.50 & 133.88 & 13.58 & 84.53 & 26.80 & 30.62 & 2.47 & 10.12 & 0.43 & 0.79 & 5.03 & 26.23 \\
\hline
\end{tabular}

Note. ${ }^{1} \mathrm{DF}=$ Days for flowering; $\mathrm{CYCLE}=$ Plant cycle, $\mathrm{NRP}=$ Number of ramifications per plant; $\mathrm{PH}=\mathrm{Plant}$ height; NSC $=$ Number of seeds per chapter; $\mathrm{NCP}=$ Number of chapter per plant; $\mathrm{DC}=$ Diameter of the chapter $(\mathrm{cm})$; DS = Diameter of the stalk $(\mathrm{cm})$; WS $=$ Width of seeds $(\mathrm{cm}) ; \mathrm{LS}=$ Length of seeds $(\mathrm{cm})$; W100 = Weight of 100 seeds and PY $=$ Plant yield. 
Regarding plant height, the safflower genotypes evaluated obtained an average of $84.53 \mathrm{~cm}$, ranging from 62 to $111 \mathrm{~cm}$ (Table 2). These results are similar to Silva (2013), where plant height varied between 57 and $136 \mathrm{~cm}$. According to Gracia et al. (2010), the observed values, for the most part, are within the limits commonly observed in the improved safflower cultivars, whose averages normally ranging between 90 and $150 \mathrm{~cm}$.

As for the number of seeds per chapter, the average obtained by the genotypes evaluated in the present study was 26.8 (Table 2). Shinwari et al. (2014) found similar results, in a work conducted in Islamabad-Pakistan, where this variable presented an average of 28.2.

Considering the number of chapters per plant, the genotypes evaluated presented values ranging from 6 to 59 (Table 2). In a study carried out by Silva (2013), in Botucatu-SP, evaluating 170 accessions of safflower, there was a variation from 9 to 78 . This parameter of production is relevant, since the larger the number of chapters per plant, the greater the number of seeds produced, which can promote productivity increases. Hajghami et al. (2009), emphasizes that to obtain promising cultivars in breeding programs, should select the materials with the highest number of chapters per plant to obtain highly productive plants. Therefore, the genotypes PI195895, PI250203, PI250840, PI253899 and PI262447 are distinguished for this characteristic producing more than 50 chapters per plant.

For the characteristic diameter of the chapter the safflower breeding programs search genotypes that present larger diameter, since the greater the chapter the greater the capacity of flower formation and, consequently, the greater the number of seeds, thus favoring productivity (Silva, 2013). Among the genotypes evaluated in the present study, PI250840 presented the highest result with a diameter of $3.16 \mathrm{~cm}$ (Table 2). This value is higher than those obtained by Atole et al. (2018), evaluating 155 safflower genotypes evaluated in Maharashtra-India, whose maximum value was $2.78 \mathrm{~cm}$ and by Silva et al. (2015), evaluating 20 genotypes evaluated in Botucatu-São Paulo, the highest value was $2.4 \mathrm{~cm}$.

The diameter of the stalk is a very important feature in a plant of the same safflower family, as the sunflower (Asteraceae). Considering that it allows less bedding of the crop, facilitating its management, treatments and harvesting (Biscaro et al., 2008). As previously reported by Anicésio (2014), the study of this variable also applies to safflower, because this crop presents bedding problems that hamper, among other steps, mechanized harvesting. Thus, in the present research the genotypes PI 195895, PI248620, PI253899, PI262443, PI279344 and PI305207 are outstanding, since they have a diameter with values equal to or greater than $12 \mathrm{~cm}$.

For the weight of 100 seeds, the genotypes varied from 3.76 to $7.10 \mathrm{~g}$ and average of $5.05 \mathrm{~g}$ (Table 2). These results are higher than those obtained by Pushpavalliet et al. (2017) evaluating 47 safflower genotypes in the 2015/16 crop in Telangana State, India, where the values obtained were $3.67 \mathrm{~g}$ maximum.

Regarding the variable plant yield, the average of the 50 safflower genotypes evaluated in the present study was $26.23 \mathrm{~g}$, with a maximum value for genotypes PI305207 with a value of $70.28 \mathrm{~g}$ (Table 2). This result is similar to that obtained by the hybrid combination between the genotypes PI537697 and PI653152 in Olivo (2017), in which the grain yield per plant was $73.80 \mathrm{~g}$.

The genetic divergence of the evaluated genotypes was based on the average Euclidean distance, in which the most dissimilar pair was composed of genotypes PI248620 and PI343783, this dissimilarity between these genotypes may be linked to their geographical origin, considering that genotype PI248620 is from Pakistan and genotype PI343783 is of Iranian origin (Table 1). These results seem to be a trend, as they were previously reported in studies conducted by Derakhsan et al. (2014), in which the genetic divergence of 42 genotypes of six species of Carthamus tinctorius L. was evaluated, via microsatellite markers, where the results indicated that, in most cases, safflower genotypes are divided into subgroups consistent with the country of origin, that is, genotypes of different geographical origin are expected to be divergent.

From the point of view of genetic improvement, the divergence between these genotypes is of great importance, since as pointed out by Cruz et al. (2004), it is recommended to cross between divergent materials, for maximum heterosis in the progenies increasing the possibility of genetic gains in the segregating populations.

In relation to similarity, genotypes PI262450 and PI305198 are the closest, this fact, can be considered, because of their origins, since both are from India, because they present this similarity, the crossing of this combination is not recommended, having since for genetic breeding programs variability is indispensable (Santos et al., 2014).

In the cluster analysis by the Tocher optimization method, based on the dissimilarity matrix using the average Euclidean distance, the formation of 13 groups was obtained (Table 3). Group I had the highest number of genotypes, comprising $58 \%$ of the genotypes evaluated; group II, V and VII were composed of two genotypes, 
constituting $4 \%$ of genotypes, group III, IV and VI were composed of three genotypes, $6 \%$ of the evaluated materials, respectively.

Table 3. Group of safflower genotypes with similar patterns, established by the Tocher method, using the average Euclidean distance as a measure of dissimilarity evaluated in the city of Cáceres, state of Mato Grosso

\begin{tabular}{lll}
\hline Groups & Genotypes $^{\mathbf{1}}$ & Frequency (\%) \\
\hline I & $24,29,28,27,4,13,33,49,35,45,36,47,14,11$, & $58 \%$ \\
II & $7,1,9,44,37,40,50,12,17,25,18,46,21,8,39$ & \\
III & 16,41 & $4 \%$ \\
IV & $15,30,3$ & $6 \%$ \\
V & $2,32,23$ & $6 \%$ \\
VI & 34,42 & $4 \%$ \\
VII & $26,31,20$ & $6 \%$ \\
VIII & 6,10 & $4 \%$ \\
IX & 19 & $2 \%$ \\
X & 22 & $2 \%$ \\
XI & 48 & $2 \%$ \\
XII & 43 & $2 \%$ \\
XIII & 38 & $2 \%$ \\
\hline
\end{tabular}

Note. ${ }^{1}$ 1-PI193473, 2-PI195895, 3-PI237539, 4-PI248385, 5-PI248620, 6-PI248808, 7-PI248828, 8-PI248839, 9-PI248852, 10-PI250083, 11-PI250188, 12-PI250190, 13-PI250203, 14-PI250204, 15-PI250840, 16-PI250922, 17-PI251978, 18-PI253540, 19-PI253899, 20-PI259996, 21-PI259997, 22-PI262443, 23-PI262447, 24-PI262450, 25-PI279344, 26-PI283757, 27-PI304438, 28-PI305161, 29-PI305198, 30-PI305207, 31-PI305209, 32-PI305540, 33-PI306832, 34-PI306833, 35-PI306838, 36-PI306844, 37-PI306866, 38-PI343783, 39-PI343930, 40-PI367833, 41-PI369842, 42-PI369845, 43-PI369849, 44-PI369854, 45-PI392029, 46-PI392030, 47-PI392031, 48-PI393500, 49-PI401474, 50-PI401475.

Groups VIII, IX, X, XI, XII and XIII presented a single genotype (Table 3), this formation of groups with only one individual confirms the existence of genetic divergence, which is a positive aspect from the point of view of the use of these genotypes in artificial hybridizations with the purpose of increasing the genetic variability. In this sense, it is indicated the choice of parents of different groups because they present greater genetic distances.

According to the dendrogram obtained by the UPGMA hierarchical method, the genotypes were collected in seven groups. Group I was subdivided into subgroup GI-A composed of genotypes PI262450, PI305198, PI283757, PI248385, PI250203, PI304438, PI305209, PI306832, PI392030, PI392029, PI401474, PI392031 and PI279344, the GI-B subgroup consisting of genotypes PI248839, PI253540, PI343930, PI251978 and PI259997.

The GI-C subgroup allocated to genotypes PI193473, PI250083 and PI248808, and the GI-D subgroup composed of the largest number of individuals, formed by genotypes PI250188, PI306833, PI306838, PI306844, PI248828, PI250204, PI306866, PI369854, PI369849, PI248852, PI250190, PI367833, PI401475, PI369842, PI250922 and PI369845 and genotype PI259996 belongs to the GI-E subgroup (Figure 1). 


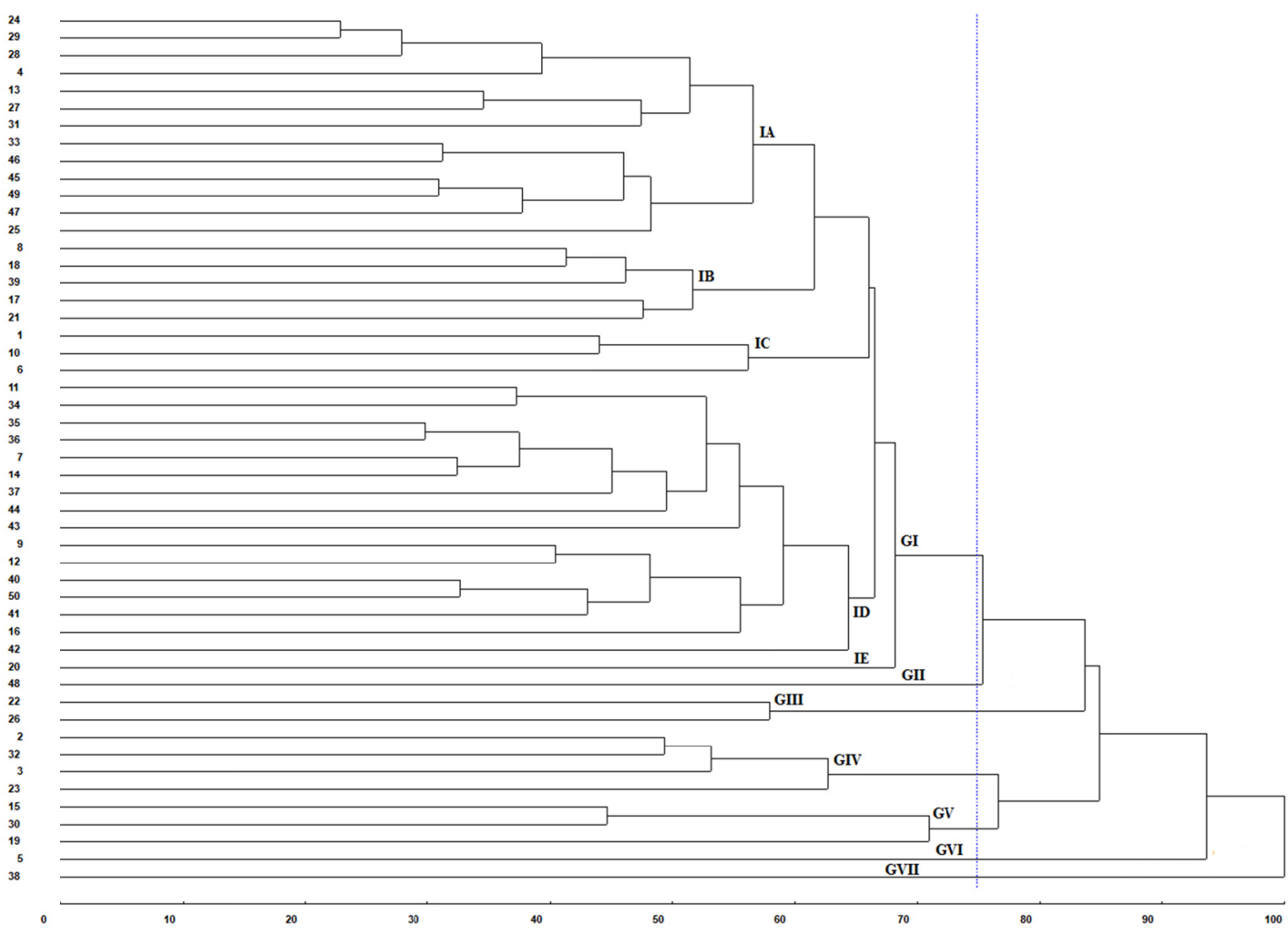

Figure 1. Dendrogram illustrating the genetic divergence among fifty genotypes of safflower, obtained by the method of average bonds (UPGMA), using the average Euclidean distance

Note. ${ }^{1}$ 1-PI193473, 2-PI195895, 3-PI237539, 4-PI248385, 5-PI248620, 6-PI248808, 7-PI248828, 8-PI248839, 9-PI248852, 10-PI250083, 11-PI250188, 12-PI250190, 13-PI250203, 14-PI250204, 15-PI250840, 16-PI250922, 17-PI251978, 18-PI253540, 19-PI253899, 20-PI259996, 21-PI259997, 22-PI262443, 23-PI262447, 24-PI262450, 25-PI279344, 26-PI283757, 27-PI304438, 28-PI305161, 29-PI305198, 30-PI305207, 31-PI305209, 32-PI305540, 33-PI306832, 34-PI306833, 35-PI306838, 36-PI306844, 37-PI306866, 38-PI343783, 39-PI343930, 40-PI367833, 41-PI369842, 42-PI369845, 43-PI369849, 44-PI369854, 45-PI392029, 46-PI392030, 47-PI392031, 48-PI393500, 49-PI401474, 50-PI401475.

The GII group allocated only one genotype: PI393500, GIII was composed of genotypes PI262443 and PI283757, genotypes PI195895, PI305540, PI237539 and PI262447 belong to the GIV group, genotypes PI250840, PI305207 and PI253899 were designated to GV, genotype PI248620 and PI343783 were determined in the GVI and GVII groups, respectively (Figure 1).

The agglomerative optimization methods Tocher and Hierarchical UPGMA were partially similar, in which group 1 of both clustering methods the largest number of genotypes, another fact of this similarity between clustering methods can be observed by the allocation of genotypes PI248620 and PI343783 in which these were allocated only in different groups.

In relation to the relative importance of the traits, the characteristics with the greatest contributions to the evaluation of the genetic diversity among the genotypes evaluated in the present study were according to the method of Singh (1981) yield per plants, chapter number per plant and plant height with 28, 82, 20.86 and 19.73\% respectively (Table 4). 
Table 4. Relative contribution of the eleven agronomic characters to the genetic divergence among fifty safflower genotypes evaluated in the city of Cáceres, state of Mato Grosso

\begin{tabular}{ll}
\hline Character $^{\mathbf{1}}$ & Relative importance (\%) \\
\hline DF & 5.0904 \\
CYCLE & 11.6188 \\
NRP & 4.2973 \\
PH & 19.7399 \\
NSC & 8.4615 \\
NCP & 20.8689 \\
DC & 0.7603 \\
DS & 0.2588 \\
W100 & 0.0829 \\
WS & 0.0002 \\
LS & 0.0005 \\
PY & 28.8205 \\
\hline
\end{tabular}

Note. ${ }^{1} \mathrm{DF}=$ Days for flowering; CYCLE $=$ Plant cycle, $\mathrm{NRP}=$ Number of ramifications per plant; $\mathrm{PH}=\mathrm{Plant}$ height; NSC $=$ Number of seeds per chapter; $\mathrm{NCP}=$ Number of chapter per plant; $\mathrm{DC}=$ Diameter of the chapter; DS = Diameter of the stalk; WS = Width of seeds; LS = Length of seeds; W100 = Weight of 100 seeds and PY = Plant yield.

In a study conducted in the state of Maharashtra, India, evaluating 155 genotypes by Atole et al. (2018), plant height and number of seeds per chapters also stood out for discrimination of genetic diversity with 22.75 and $20.68 \%$, respectively. In the research carried out by Tayade et al. (2015), in Akola, India, evaluating 155 genotypes and five safflower varieties, the number of chapters per plant characteristics was also an important trait with $26.98 \%$ relative importance.

The trait that contributed less to diversity, were seed size per width and seed size per length. Tayade et al. (2015) obtained divergent results, where the characteristics that contributed least were hull content and weight of 100 seeds, with 0.00 and 0.05 , respectively.

\section{Conclusion}

The safflower genotypes analyzed presented genetic divergence regarding the agronomic traits and the highest dissimilarity were PI248620 and PI343783, on the other hand, the less divergent genotypes were PI262450 and PI305198. The Tocher clustering and UPGMA hierarchical methods were partially concordant in ordering the similar accessions. The characteristics yield per plant and chapter number per plant are the ones that contributed the most for genetic dissimilarity in the safflower genotypes evaluated in the present research.

\section{Acknowledgements}

The authors are grateful to Fundação de Amparo à Pesquisa do Estado de Mato Grosso (FAPEMAT) and Conselho Nacional de Desenvolvimento Científico e Tecnológico (CNPq) for granting a scholarship.

\section{References}

Anicésio, E. C. A. (2014). Nitrogênio e potássio na adubação do cártamo cultivado em latossolo vermelho (Dissertação de Mestrado em Engenharia Agrícola, Universidade Federal do Estado de Mato Grosso, Rondonópolis, Mato Grosso, Brazil).

Arantes, E. M., Cremon, C., \& Luiz, M. A. C. (2012). Alterações dos atributos químicos do solo cultivado no sistema orgânico com plantio direto sob diferentes coberturas vegetais. Revista Agrarian, 5(15), 47-54.

Atole, N. A., Rathi, R. D., Ratnaparkhi, R. D., \& Janjal, S. M. (2018). Genetic diversity analysis in selected germplasm lines of safflower (Carthamus tinctorius L.). Electronic Journal of Plant Breending, 9(1), 213-219. https://doi.org/10.5958/0975-928X.2018.00025.X

Bellé, R. A., Rocha, E. K. da, Backes, F. A. A. L., Neuhaus, M., \& Schwab, N. T. (2012). Safflower frown in different sowing dates and plant densities. Ciência Rural, 42(12), 2145-2152. https://doi.org/10.1590/ S0103-84782012005000106 
Biscaro, G. A., Machado, J. R., Tosta, M. da S., Mendonça, V., Soratto, R. P., \& Carvalho, L. A. de. (2008). Adubação nitrogenada em cobertura no girassol irrigado nas condições de Cassilândia-MS. Ciência e Agrotecnologia, 32(5), 1366-1373. https://doi.org/10.1590/S1413-70542008000500002

Borém, A., \& Miranda, G. V. (2005). Melhoramento de plantas (4th ed.). Viçosa, UFV.

Carvalho, L. P., Lanza, M. A., Fallieri, J., \& Santos, J. W. (2003). Análise da diversidade genética entre acessos de banco ativo de germoplasma de algodão. Pesquisa Agropecuária Brasileira, 38(10), 1149-1155. https://doi.org/10.1590/S0100-204X2003001000003

Cruz, C. D. (2013). Genes-A software package for analysis in experimental statistics and quantitative genetics. Acta Scientiarum, 35(3), 271-276.

Cruz, C. D., Regazzi, A. J., \& Carneiro, P. C. S. (2004). Modelos biométricos aplicados ao melhoramento genético (3rd ed.). Viçosa, UFV.

Dallacort, R., Neves, S. M. A. S., \& Nunes, M. C. M. (2014). Variabilidade da Temperatura e das Chuvas de Cáceres/Pantanal Mato-Grossense-Brasil. Geografia (Londrina), 23(1), 21-33.

Derakhshan, E, Majidi, M. M., Sharafi, Y., \& Mirlohi, A. (2014). Discrimination and genetic diversity of cultivated and wild safflowers (Carthamus ssp.) using EST-microsatellites markers. Biochemical Systematic and Ecology, 54, 130-136. https://doi.org/10.1016/j.bse.2014.01.003

Ferrão, M. A. G., Vieira, C., Cruz, C. D., \& Cardoso, A. A. (2002). Divergência genética em feijoeiro em condições de inverno tropical. Pesquisa Agropecuária Brasileira, 37(8), 1089-1098. https://doi.org/ 10.1590/S0100-204X2002000800006

Galant, N. B., Santos, R. F., \& Silva, M. A. (2015). Melhoramento de cártamo (Carthamus tinctorius L.). Acta Iguazu, 4(1), 14-25.

Gerhardt, I. F. S. (2014). Divergência genética entre acessos de cártamo (CarthamusTincorius L.) (35f., Dissertação (Dissertação de Mestrado em Agronomia), Universidade Estadual Paulista "Júlio de Mesquita Filho", São Paulo, Brazil).

Gracia, A. B., Esponiza, X. M. O., Márquez, J. P., Camarena, M. G. G., Cervantes, J. M., \& Coronado, L. M. (2010). Guia para produzir cártamo em Sinaloa. Fundación Produce, Sinaloa México.

Hajghani, M., Saffari, M., \& Maghsoudi Moud, A. A. (2009). Path Coefficient Analysis for the Yield Components of Spring Safflower Cultivars (Carthamus tinctorius L.) in Iran under Different Nitrogen Levels. American-Eurasian Journal of Agricultural \& Environmental Sciences, 6(6), 737-740.

Ivoglo, M. G., Fazuoli, L. C., Oliveira, A. C. B., Gallo, P. B., Mistro, J. C., Silvarolla, M., \& Toma-Braghini, B., (2008). Divergência genética entre progênies de café robusta. Bragantia, 67(4), 823-831. https://doi.org/ 10.1590/S0006-87052008000400003

Moura, P. C. S., Bortolheiro, F. P. A. P., Guimarães, T. M., Leal, D. P. V., \& Silva, M. A. (2015). Características gerais e ecofisiologia do cártamo (Carthamus tinctorius). Journal of Agronomic Sciences, 4, 136-150.

Olivo, M. (2017). Cruzamento dialélicos $F_{1}$ e $F_{2}$ em cártamos (Carthamus tinctorius L.) (Tese de doutorado em Agronomia, Universidade Estadual Paulista, Botucatu, São Paulo, Brazil).

Pavithra, K. P., Patil, R. S., Harijan, Y., \& Nishanth, G. K. (2015). Assessment of genetic diversity in safflower (Carthamus tinctorius L.) germplasms. International Journal of Agricultural, 5(5), 151-158.

Pushpavalli, S. N. C. L. V., Reddy, T. R., Kummar, G., \& Sudhakar, C. (2017). Genetic divergence, correlation and path analysis for the yield componentes of safflower genotypes (Carthamus tinctorius L.). Life Sciences International Research Journal, 4, 98-102.

Safavi, S. M., Pourdad, S. S., \& Safavi, S. A. (2012). Assessment of genetic diversity in safflower (Carthamus tinctorius L.) genotypes using agro-morphological traits. Annals of Biological Research, 3(5), 2428-2432.

Santos, J. A, S., Teodoro, P. E., Correa, A. M., Soares, C. M. G., Ribeiro, L. P., \& Abreu, H. K. A. (2014). Desempenho agronômico e divergência genética entre genótipos de feijão-caupi cultivados no ecótono Cerrado/Pantanal. Bragantia, 73(4), 377-382. https://doi.org/10.1590/1678-4499.0250

Shinwari, Z. K., Rehman, H., \& Rabbani, M. A. (2014). Morphological traits based diversity in Safflower (Carthamus tinctorius L.). Pakistan Journal of Botany, 46(4), 1389-1395.

Shivani, D., Sreelakshmi, C. H., \& Kumar, C. V. S. (2010). Genetic divergence studies in safflower, Carthamus tinctorius L. Electronic Journal of Plant Breeding, 1(5), 1354-1357. 
Silva, C. J. (2013). Caracterização agronômica e divergência genética de acessos de cártamo (Tese de Doutorado em Agronomia/Agricultura, Faculdades de CiênciasAgronômicas de Botucatu, Universidade Estadual Paulista "Julio de Mesquita Filho", Botucatu, SãoPaulo, Brazil).

Silva, C. J., Silva, A. C., Zoz, T., Toppa, E. V. B., Silva, P. B., \& Zanotto, M. D. (2015). Genetic divergence among accessions of Carthamus tinctorius L. by morphoagronomic traits. African Journal of Agricultural Research, $12(52), 4825-4830$.

Singh, D. (1981). The relative importance of characters affecting genetic divergence. Indian Journal of Genetic and Plant Breeding, 41, 237-245.

Tayade, S. D, Ratnaparkhi., R. D., Gundewadi, V. B., Nichal, S. S., \& Mali, R. S. (2015). Genetic divergence for seed related characters in selected germplasm of safflower (Carthamus tinctorius L.). Electronic Journal of Plant Breeding, 6(3), 875-880.

Zoz, T. (2015). Avaliação de genótipos de cártamo quanto ao desempenho agronômico, divergência genética e produtividade da água (Tese de doutorado em Ciências Agrárias, Universidade Estadual Paulista Júlio de Mesquita Filho, São Paulo, Brazil).

\section{Copyrights}

Copyright for this article is retained by the author(s), with first publication rights granted to the journal.

This is an open-access article distributed under the terms and conditions of the Creative Commons Attribution license (http://creativecommons.org/licenses/by/4.0/). 